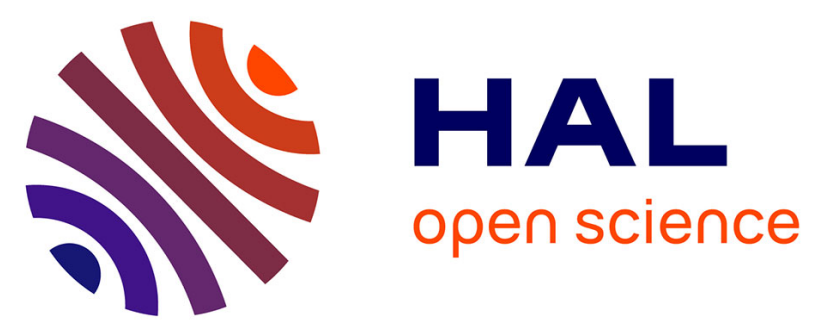

\title{
At the dawn of Arabian fisheries: Fishing activities of the inhabitants of the Neolithic tripartite house of Marawah Island, Abu Dhabi Emirate (United Arab Emirates)
}

Kevin Lidour, Mark Jonathan Beech

\section{To cite this version:}

Kevin Lidour, Mark Jonathan Beech. At the dawn of Arabian fisheries: Fishing activities of the inhabitants of the Neolithic tripartite house of Marawah Island, Abu Dhabi Emirate (United Arab Emirates). Arabian Archaeology and Epigraphy, 2020, 31 (1), pp.140-150. 10.1111/aae.12134 . hal03418251

\section{HAL Id: hal-03418251 \\ https://hal.science/hal-03418251}

Submitted on 6 Nov 2021

HAL is a multi-disciplinary open access archive for the deposit and dissemination of scientific research documents, whether they are published or not. The documents may come from teaching and research institutions in France or abroad, or from public or private research centers.
L'archive ouverte pluridisciplinaire HAL, est destinée au dépôt et à la diffusion de documents scientifiques de niveau recherche, publiés ou non, émanant des établissements d'enseignement et de recherche français ou étrangers, des laboratoires publics ou privés. 


\begin{abstract}
At the dawn of Arabian fisheries. Fishing activities of the inhabitants of the Neolithic tripartite house of Marawah Island, Abu Dhabi Emirate (United Arab Emirates)
\end{abstract}

\title{
Kevin Lidour ${ }^{1,2}$, Mark Jonathan Beech ${ }^{3}$
}

1. Université Paris 1 Panthéon-Sorbonne, UMR 7041 (ARSCAN), 21 allée de l'Université, 92023, Nanterre, France.

2. Muséum National d'Histoire Naturelle, UMR 7209 (AASPE), CP 56, 55 rue Buffon, 75005 Paris, France.

3. Historic Environment Department, Department of Culture and Tourism (DCT), Nation Towers Corniche, PO Box 94000, Abu Dhabi, UAE.

Corresponding author: Kevin Lidour, lidour01@gmail.com

\begin{abstract}
This paper presents the results of a study of nearly 8000 fish bones from MR11 Area A, a Neolithic stone build house located on Marawah Island, United Arab Emirates. Radiocarbon dating indicates that the site was inhabited from the first half of the $6^{\text {th }}$ to the mid- $5^{\text {th }}$ millennium BC, making it one of the oldest Neolithic occupation sites in the whole of the Arabian Gulf. Initial excavations between 2003-4 revealed a single room and then more recent excavations in 2016-17 uncovered two adjacent structures which proved to be a tripartite house. Examination of the fish remains from this particular site allows both a spatial and diachronic analysis. Archaeo-ichthyological studies can determine the role of fisheries within the subsistence strategies of past societies and the fishing techniques they adopted. This study provides important evidence regarding coastal and island lifestyle during the Neolithic. It outlines the predominance of small coastal fish such as grunts, emperors, and seabreams in the faunal assemblage. It thus suggests that fishing was essentially carried out in the surrounding shallow waters where softbottoms and seagrass meadows predominate. Non-selective fishing techniques probably involved the use of small-mesh devices such as beach seines and coastal barrier traps.
\end{abstract}

Keywords: Ancient fishing; Archaeo-ichthyology; Marawah; Neolithic; Arabian Gulf; Eastern Arabia 
Introduction

\section{Environmental settings}

Marawah Island lies about $15 \mathrm{~km}$ off the main coastline of the Emirate of Abu Dhabi, measuring about $4 \mathrm{~km}$ from North to South by $14 \mathrm{~km}$ from East to West. The island is surrounded by the Arabian Gulf waters to the north and by the Khor al-Bazm to the south (Figure 1). Marawah Island is composed of several low limestone outcrops linked by unconsolidated marine deposits (Evans et al., 2002). By the Early Holocene, the marine transgression is estimated to have been at least c.2-3 m above the actual modern-day sea level (Sanlaville \& Dalongeville, 2005), suggesting that the island appeared as a small archipelago at that time. While the tidal range is low in the southern Arabian Gulf (between $0.2 \mathrm{~m}$ and $1.5 \mathrm{~m}$ ), the foreshore slopes are quite gentle and thus expose wide bare areas during ebb tide. Intertidal zones contain a wide diversity of marine habitats and life forms. The nearest seabed is shallow and characterised by fringing reefs and tidal ridges frequently occupied by seagrass (mostly Halodule univervis and some Halodule ovalis) and macroalgae beds (Rhizoclonium tortuosum, Chaetomorpha gracilis, and Cladophora coelothrix). Sparse coral patches are essentially composed of Porites species. Shorelines are dominated by sand beaches and a few mangrove stands of Avicennia marina. Since 2007, the Marawah Marine Biosphere Reserve covers a protected area of 425000 ha, and is home to representative natural habitats and wildlife with biodiversity significance such as dugongs and marine turtles.

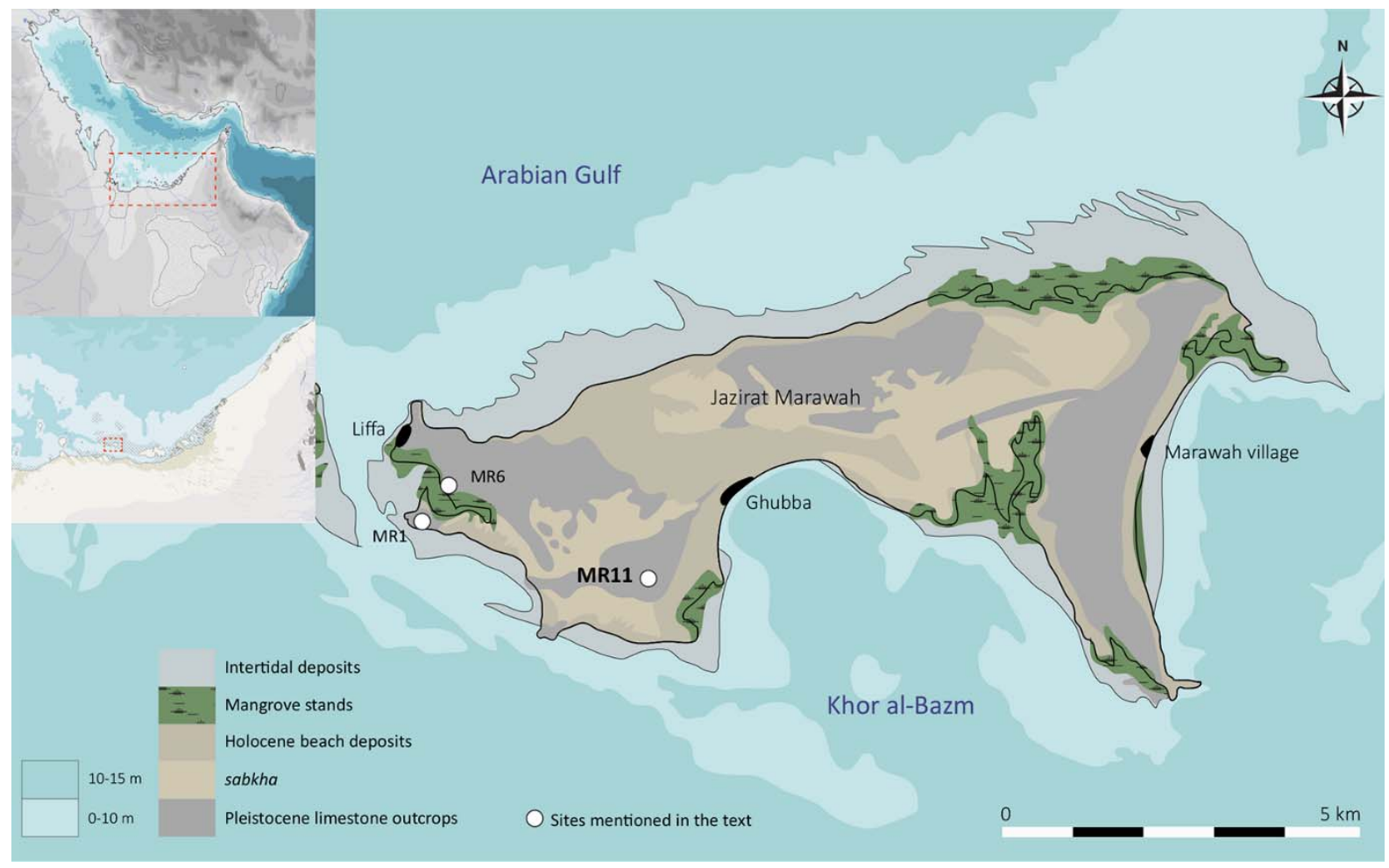

Figure 1. A map of Marawah Island showing the location of the sites mentioned in the text. 


\section{Archaeological settings}

The Prehistoric occupation at Marawah is documented by a few surface sites where several

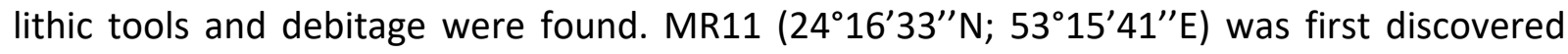
during a survey campaign conducted in 1992 by the Abu Dhabi Islands Archaeological Survey (ADIAS) project (King, 1998). The site consists of a group of seven stone mounds located on the top of a limestone platform in the south-western part of the island. At MR11.6 (re-designated as Area A), new campaigns of excavations undertaken by the Department of Culture and Tourism of Abu Dhabi between 2003 and 2016 have revealed a unique tripartite stone built house dating back to the Neolithic (Beech et al., 2005; Beech et al., 2016).

The occupation layer is thin and directly settled on the natural limestone bedrock (Phase 1). The material culture includes several lithic tools such as flint tile knives, arrowheads, and debitage. Beads and other personal ornaments such as buttons in pearl oyster shell have also been found. It is interesting to note that Marawah and Delma (UAE) are the only two Neolithic sites from the Gulf region where the remains of plaster vessels were found - suggesting a production specific to the southern UAE. This vessel is often decorated with painted geometric patterns which seem to be inspired by 'Ubaid pottery wares. Room 1 from the tripartite house has provided the remains of an almost complete Mesopotamian pot whose stylistic attribution can be assigned to an Ancient 'Ubaid phase (Méry et al., 2016), supported by radiocarbon dates as early as the first half of the $6^{\text {th }}$ millennium BC (SUERC-3612: $6750+/-40$ BP, 5725-5617 cal. BC $2 \sigma$ and SUERC-3608: $6675+/-40$ BP, 5562-5526 cal. BC $2 \sigma^{1}$ ). In Phase 2, the structure hosted several burials, but the associated levels are quite disturbed. It is likely that the domestic occupation did not persist as the passageway between Room 1 and Room 2 was closed to install a burial. The latest levels are associated to the collapse of the structure (Phase 3). The final occupation was identified just below the modern-day ground surface, outside the tripartite house. It was radiocarbon dated to the mid- $5^{\text {th }}$ millennium BC (SUERC-1182: $5630+/-$ $50 \mathrm{BP}, 4554-4351$ cal. BC 20).

Faunal remains were collected from the three different phases. These are mostly composed of marine shells and fish bones. The main shellfish consumed are sunset clams (Asaphis violascens), crowned turban shells (Lunella coronata), and pearl oysters (Pteriidae). It reflects the exploitation of various soft and rocky bottoms situated in the intertidal zone and below. The faunal assemblage also includes a few marine turtle, terrestrial (gazelle or sheep/goat) and marine mammal (dugong and dolphin) remains. A number of small rodent and bird bones as well as eggshell fragments were also found in certain contexts. It suggests ephemeral reoccupations of the site by wildlife (Beech et al., 2005: fig. 14-15).

\section{Material and methods}

All the excavated sediments were systematically dry-sieved using a $4 \mathrm{~mm}$ mesh screen. A fine sieving $(1 \mathrm{~mm}$ ) was also conducted in a small hearth (Context 63) associated with Phase 1 to test for the presence of charcoals and microfauna. It provided the remains of small planktivorous fish such as sardines (Clupeidae), anchovies (Engraulidae), and silversides

\footnotetext{
${ }^{1}$ Calibration according Calib 7.1. Intcal 13 (Reimer et al. 2013)
} 
(Atherinidae). It highlights the importance of fine sieving at archaeological sites whose economies were greatly oriented toward fishing. Sun-dried or used to prepare fermented sauces, small fish often have a great place in the diet of coastal societies.

The bone preservation at MR11 is quite good in comparison to other Neolithic sites from coastal Arabia where calcite or salt encrustations are regularly observed. However, because these encrustations tend to harden the bones, their relative absence at MR11 led to accentuate the fragmentation. Anatomical and taxonomic identifications were conducted according to the methods of comparative anatomy, using two osteological collections of Arabian Gulf fish specimens: M. J. Beech's personal collection during a two-month visit to Abu Dhabi in 2017 and the collection of the National Natural History Museum of Paris in 2017-18. NISP stands for the 'number of identified specimens', MNI for the 'minimum number of individuals', and WISP for the 'weight of identified specimens'. MNI quantifications are calculated according to the combination method: the frequency of bones is combined with laterality and size/weight estimations (Chaplin, 1971). We estimated the average fresh weights of fish after visual comparisons of archaeological bones with reference specimens (Wheeler \& Jones, 1989: 141).

\section{Results}

A total of 7536 fish bones fragments were retrieved and recorded of which 2786 could be identified to the level of family, genus, or species (Table 1). A total of 4 families of cartilaginous fish and 23 families of bony fish are represented at Marawah including bamboo-sharks (Hemiscylliidae), requiem-sharks (Carcharhinidae), sawfish (Pristidae), stingrays (Myliobatiformes), anchovies (Engraulidae), sardines (Clupeidae), sea catfish (Ariidae), mullets (Mugilidae), silversides, needlefish (Belonidae), flatheads (Platycephalidae), groupers (Serranidae), sillagos (Sillaginidae), jacks and trevallies (Carangidae), snappers (Lutjanidae), mojarras (Gerreidae), grunts (Haemulidae), threadfin breams (Nemipteridae), emperors (Lethrinidae), seabreams (Sparidae), drums (Sciaenidae), goatfish (Mullidae), grunters (Terapontidae), parrotfish (Scaridae), rabbitfish (Siganidae), barracudas (Sphyraenidae), and tuna (Scombridae). This included at least 37 genera and 43 species. 


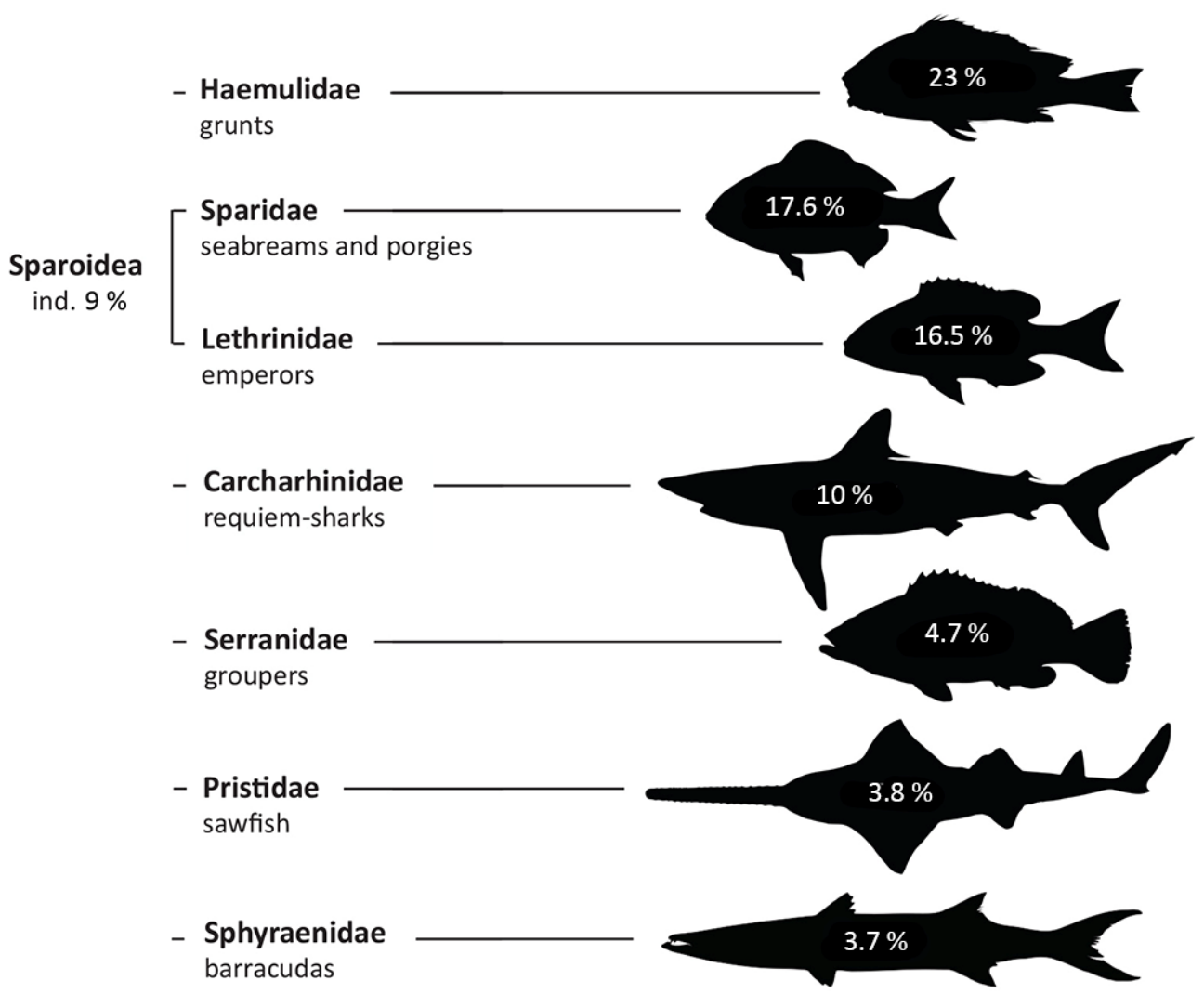

Figure 2. Proportions of the main families identified at MR11 Area A. NISP = 2786; other fish $\operatorname{taxa}=11.8 \%$.

According to NISP, the assemblage is mainly dominated by grunts (23\%), seabreams (17.5\%), emperors (16.5\%), requiem-sharks (10\%), groupers (5\%), sawfish (4\%), and barracudas (4\%) (Figure 2). The superfamily Sparoidea (i.e. sparoid fish) includes Nemipteridae, Lethrinidae, and Sparidae. Grunts are essentially represented by the striped piggy and emperors by the spangled emperor (Lethrinus nebulosus). Seabreams are dominated by the haffara seabream (Rhabdosargus haffara) and by species belonging to the Acanthopagrus genus. Groupers mostly belong to the Epinephelus genus. In most cases, both vertebrae and teeth of requiemsharks and sawfish generally do not allow identification to species level. Almost all the specimens of emperors and seabreams caught are small-sized fish comprised between 100 and 400 grams (from 20 to $25 \mathrm{~cm}$ in length) (Figure $3 \mathrm{C}$ ). Striped piggies (Pomadasys stridens) are roughly estimated between 50 and 150 grams (c. 18-22 cm in length). Besides, groupers, jacks and trevallies generally weighed between 1 and $2 \mathrm{~kg}$ (from 40 to $60 \mathrm{~cm}$ in length). It is likely that the sharks and sawfish caught were essentially small specimens as the diameter of the vertebrae rarely exceeded $1 \mathrm{~cm}$ in width.

All the main anatomical elements belonging both to the skull and the backbone are represented in the assemblage. Because significantly harder and thus generally better preserved, jaw bones (i.e. dentaries, premaxillae, and maxillae), vertebral centra and otoliths were mostly recorded (Figure $3 \mathrm{~A}-\mathrm{B}$ ). Indeed, a large number of otoliths were recovered at the site (NISP $=1066-c .30 \%$ of the total NISP). Otoliths are calcified structures located in the inner ear of teleost fish and are generally very diagnostic to species (Figure $\left.4 n^{\circ} 1-4\right)$. Most of 
the otoliths identified belong to striped piggies, spangled emperors, haffara seabreams, and groupers. In the absence of butchery marks, it is likely that fish were directly brought to the site in a relatively complete form. Likewise, the preferential dispatching of fire marks on the less fleshy parts of the skeleton (e.g. opercle series, spines and external tips of the jaw bones) suggests that whole fish were probably grilled on coals. However fire marks remain rare on the bone assemblage (only $4 \%$ of the global NISP).

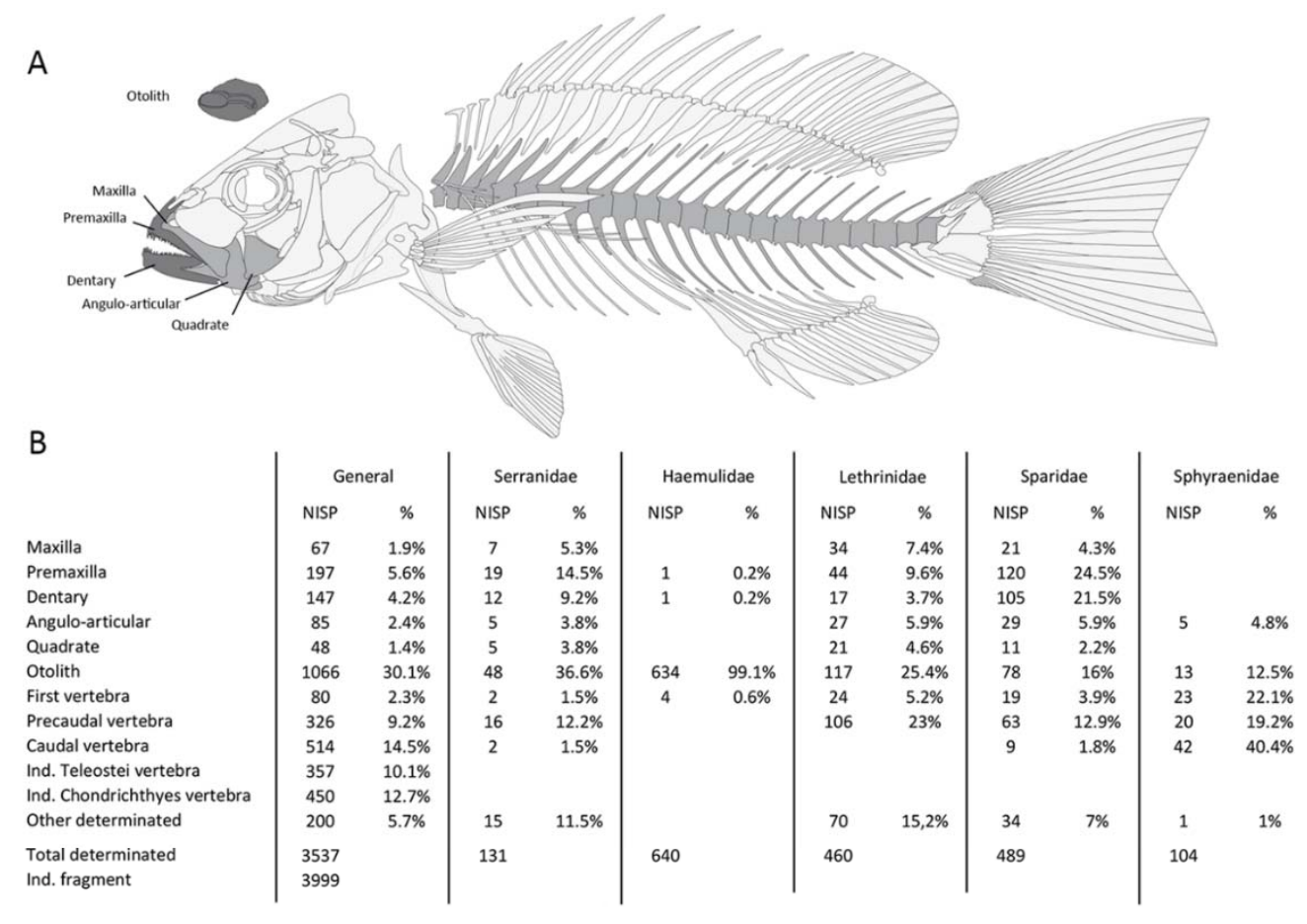

C

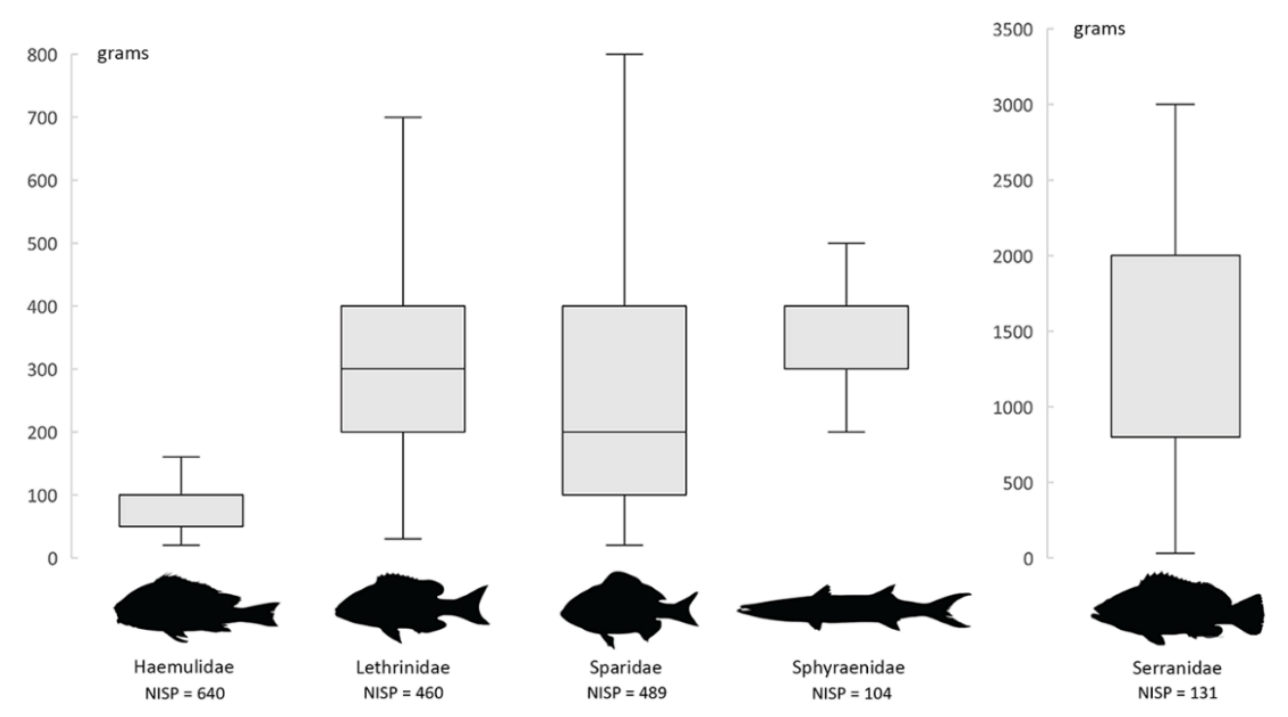

Figure 3. A. Anatomical representation of the fish bones from MR11 Area A (bony fish skeleton modified from Coutureau \& Béarez, 2012); B. Distribution of anatomical elements for some of the main taxa identified. C. Box plots of fresh weights for the main taxa identified (based on estimations according to visual comparisons with reference specimens). 


\section{Discussion}

\section{Fishing grounds and techniques}

The majority the fish taxa identified at MR11 could be caught in the vicinity of the site, in the surrounding shallow waters (Al-Lamy et al., 2012).

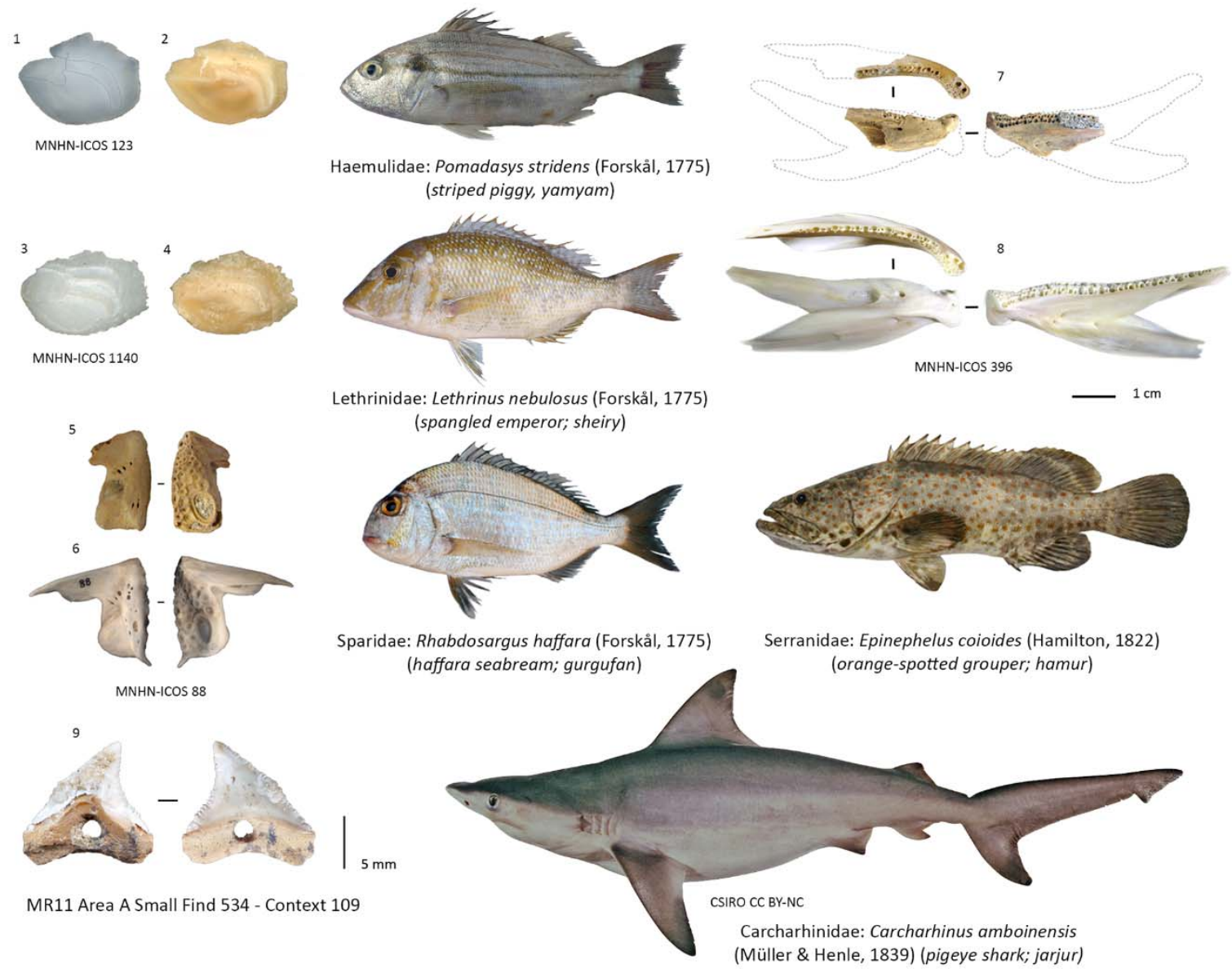

Figure 4. Sample of remains belonging to bony fish (Teleostei) from MR11 Area A compared to analogue bones from the MNHN osteological reference collection, and corresponding live pictures of the species (C Lidour \& Béarez): 1-2. Right sagittae of striped piggy, Pomadasys stridens; 3-4. Right sagittae of spangled emperor, Lethrinus nebulosus; 5-6. Right premaxilla of haffara seabream, Rhabdosargus haffara; 7-8. Right dentary of orange-spotted grouper, Epinephelus coioides; 9. A tooth of a pigeye shark, Carcharhinus amboinensis. As they are quite similar, the pigeye shark and the bull shark (Carcharhinus leucas) are often confused. Note the hole drilled in the tooth, suggesting its use as a personal adornment.

While the ecology of the striped piggy remains very sketchy in the Arabian Gulf, it is likely that small specimens should be encountered in seagrass meadows and mangroves according to local fishermen and divers that we interviewed. This is consistent with the ecology of other 
species of grunts (Weinstein \& Heck, 1979). Small emperors mainly inhabit sheltered water environments such as lagoons and mangroves, especially over seagrass beds (e.g. Kanashiro, 1998). Several small species of seabreams are widely distributed in the Arabian Gulf, such as the Arabian yellowfin seabream (Acanthopagrus arabicus), the Gulf seabream (Acanthopagrus sheim) and the haffara seabream (Iwatsuki, 2013). They form a substantial part of regional landings as they are abundant in inshore waters, in particular over soft bottomed areas. While essentially mentioned as reef fish, certain species of groupers such as the orange-spotted grouper (Epinephelus coioides) are often encountered in turbid waters, among estuaries and mangroves in particular (Sheaves, 1995). Others species identified such as small barracudas (Sphyraena sp.), snappers (Lutjanus sp.), sillagos, silversides, and anchovies are also commonly well associated to seagrass beds and mangroves (Thollot, 1996). Requiem-sharks are relatively common in coastal environments in UAE, including the spot-tail shark (Carcharhinus sorrah) and the milk shark (Rhizoprionodon acutus) which are the commonest species caught (Jabado et al., 2015). Small sawfish are often encountered inshore, especially over sandy patches and seagrass beds (Jabado et al., 2017). A few vertebrae were identified as belonging to bamboosharks (Chiloscyllium sp.) thanks to their radial asterospondylic structure (White, 1937: pl. 29, i). The arabian bamboo-shark (Chiloscyllium arabicum) is abundant in UAE waters, in particular over shallow coral reefs and seagrass beds (Jabado et al., 2018). A drilled shark tooth (Small Find \#534) was found in Context 109 in Room 2 (Figure $4 n^{\circ} 9$ ). The tooth belong to a pigeye shark (Carcharhinus amboinensis) recognizable with a distinctive angulation on its mesial side. While drilled shark teeth are well attested during the Neolithic in Oman, the specimen found at Marawah is the only known example for this period in the Arabian Gulf. Charpentier et al. (2009) have suggested that single hole teeth were used as pendants rather than as projectile points which is the case of the bi-perforated teeth (Santini, 2002).

The exploitation of a wide spectrum of small fish in shallow waters suggest the use of nonselective techniques such as beach seines and coastal barrier traps. A few notched pebbles were found at MR11. These could be interpreted as sinkers for small nets. According to HeardBey (1986: 175), small seines were traditionally used by UAE fishermen within techniques such as idfarah (set on foot) and yal (set from a small boat). Simple fish traps probably also existed in Eastern Arabia during the Neolithic (Cleuziou \& Tosi, 2007: 53). The traditional hadra traps consists of semi-permanent intertidal fences supported by rows of stones disposed perpendicular to the shoreline. The $V$ shape is a funnel which encloses fish at the falling tide. Many other regional variants of barrier traps exist such as the meskar (stone dams), and the sakkar/iskar (net stakes or baulk nets). Tidal traps are able to catch a wide range of inshore fish including emperors, seabreams, grunts as well as small specimens such as sardines, silversides, and anchovies (Abou-Seedo, 1992; Beech, 2004: 45-46; al-Baz et al., 2013). As the identification and the dating of intertidal features is hard, the possible remains of fishing traps detected on the Abu Dhabi coastline (Beech, 2003) cannot clearly be attributed to the Neolithic period. While the use of baited cage traps (similar to the traditional gargur) was recently suggested to catch sea catfish at as-Sabiyah (Kuwait) and groupers at Delma (Beech, 2010; Lidour \& Beech, 2019), it is quite unlikely that sharks, rays, and very small fish were caught by this way in Marawah. Evidence of open-water fishing are quite elusive since only a few remains belonging to pelagic taxa have been identified in the assemblage (NISP Scombridae $=19$ ). While tuna schools are encountered in the open-sea, single individuals could be caught in shallow waters, close to the shore. Because the open-waters are far off Marawah Island and thus hard to access, fishing was thus limited to the surrounding grounds. 


\section{Spatial distribution and phasing}

The taxonomic spectrum is similar between the rooms, while we can note some slight variations (Figure $5 \mathrm{~A}$ ). The proportions of grunts and barracudas are significantly higher in Room 2 and those of sparoid fish in Rooms 1 and 3. Only a few contexts located outside the tripartite house have been excavated. They essentially provided otoliths which are belonging to grunts, emperors, seabreams, and groupers. Since otoliths are hard structures, it is likely that they are more resistant to weathering outside the stone built house than the other fish remains. In Shagra (Qatar), Desse (1988: 164) also suggested that the absence of fish bones outside of the stone structure was due to taphonomic bias. Because mostly grunts were identified from otoliths in our study (Figure 3 B) - unlike the other main taxa - their prevalence in certain contexts could be directly correlated to the better preservation of otoliths. The distribution of the main families throughout the phasing sequence confirms the predominance of grunts, emperors and seabreams throughout the site occupation (Figure $5 \mathrm{~B}$ ). However, there is a striking increase in the proportion of grunts which is from $18 \%$ in Phase 1 to $25 \%$ in Phase 2, and to $35 \%$ in Phase 3. Since Phase 2 and 3 are not consistent with a domestic occupation strictly speaking, we presume that the faunal remains they provided originate from anthropogenic layers disrupted by the collapse of the structure. As some of these rubble deposits were probably exposed on surface for a while, here too, taphonomic bias cannot be excluded. According to our personal investigation of osprey diet on Marawah Island, it is not likely that numerous otoliths were derived from fish consumption by raptors after the site was abandoned.

\section{Seasonality}

The majority of fish identified could have been caught all year round in the vicinity of the site (e.g. grunts, emperors, seabreams, groupers, and cartilaginous fish). Several recent archaeoichthyological studies suggest that fishing could have been potentially carried out during a great part of the year as certain environments such as mangroves and reefs stay productive long enough (Beech, 2004: 201-207; Lidour et al., 2018; Lidour \& Beech, 2019). Further investigations are however necessary to bring to light a possible sedentary lifestyle on the coast during the Neolithic (e.g. Cavulli \& Scaruffi, 2013; Mashkour et al., 2016). The large number of otoliths found at the site encourage schlerochronological investigations in the future.

\section{Site comparisons}

MR1 is situated on a limestone outcrop distant about $3 \mathrm{~km}$ from MR11 on the south-western coast of the island (Figure 1). The material surface is mainly composed of lithic industries such as arrowheads which confirm a Neolithic occupation (Charpentier, 2004). While the site was not yet properly excavated, a few fish bones were studied from locus MR1.54 (Beech, 2004: 124-125): two sawfish vertebrae and a seabream premaxilla were recorded. It is likely that the fishing techniques at MR11 and MR1 were quite similar. Several other archaeological sites 
were surveyed on Marawah Island - most of them date back to the Islamic period. The comparison of their faunal assemblages is quite hard because of the small number of remains they provided. Small needlefish, emperors, seabreams, and scads (small carangids) were among the most common fish identified. It indicates the local perseverance of the simple and non-selective fishing techniques already adopted by the island inhabitants during the Neolithic. A number of parrotfish remains were identified at MR6.1 (Early Islamic), suggesting the exploitation of coral grounds (Beech, 2004: 125-126).

As early as the $8^{\text {th }}$ millennium BC, the inhabitants of Natif 2 Cave (Dhofar, Sultanate of Oman) probably already used seines to catch small sardinellas and anchovies (Charpentier et al., 2016). Likewise, during the $6^{\text {th }}$ and $5^{\text {th }}$ millennium BC, the fisheries from Bahrain (al-Markh J19) and Qatar (Khor P, FB, Shagra) are also characterised by the great occurrence of small planktivorous fish like sardines and silversides (Desse, 1988; Von den Driesch \& Manhart, 2000), which suggest the use of small-mesh devices along the shorelines. It is likely that small seines and barrier traps were the oldest devices used to fish in Eastern Arabia before the development of more advanced techniques such as cage trapping, luring and net setting in open-waters from boats as presumed in the fisheries of Dosariyah (Saudi Arabia), Delma, and Akab (UAE) (Uerpmann \& Uerpmann, 2018; Lidour \& Beech, 2019; Lidour et al., 2019). Firing arrows, spearing, and harpooning may have also been utilised according to ethnographic records (e.g. Serjeant, 1992) but such methods are not yet clearly evidenced during the Neolithic in Eastern Arabia. Overall, the fish fauna identified at MR11 Area A fits within the majority of the other Neolithic assemblages known in the Arabian Gulf where significant quantities of seabreams, emperors, groupers, and cartilaginous fish were also reported. 


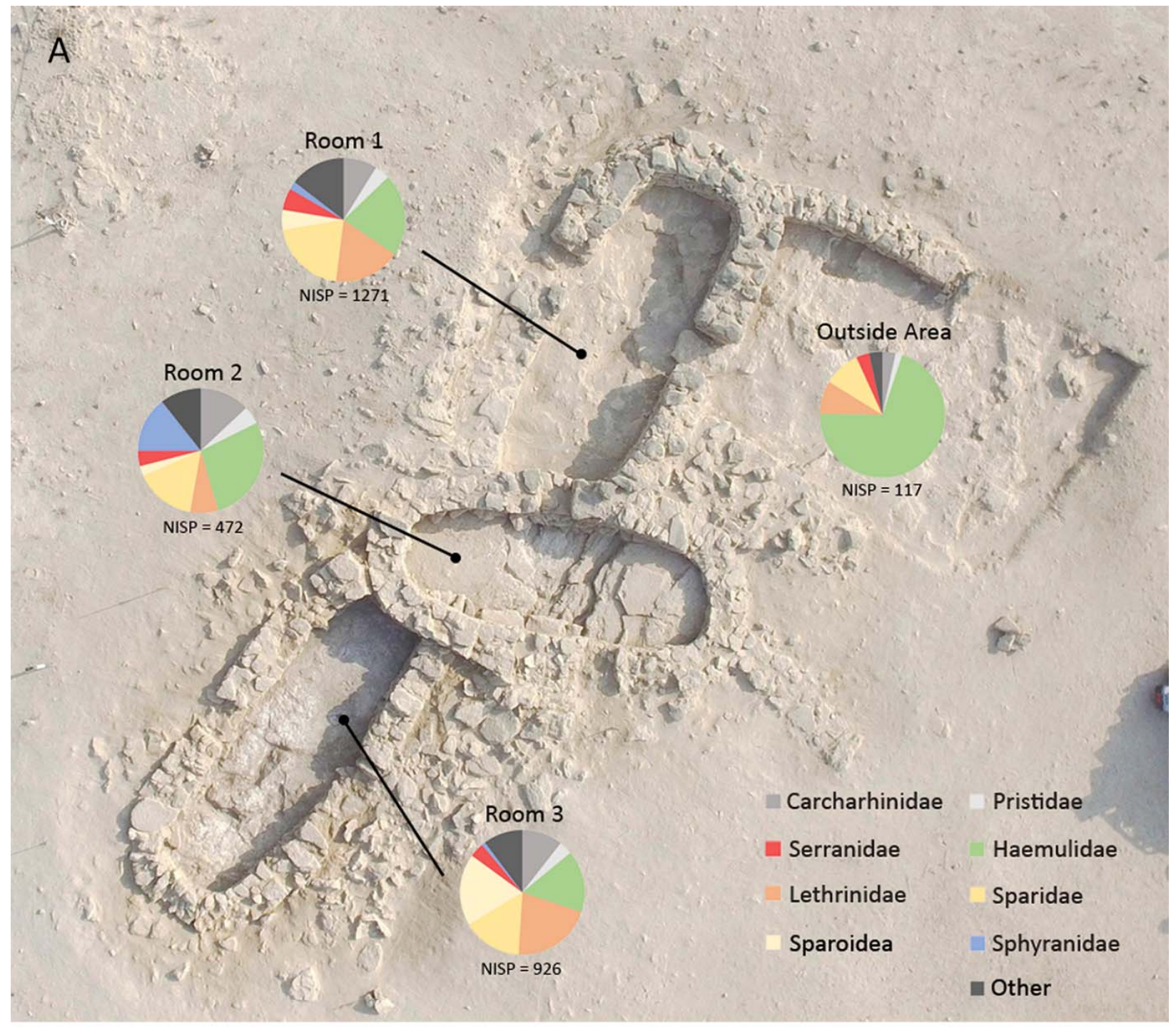

B

Phase 3
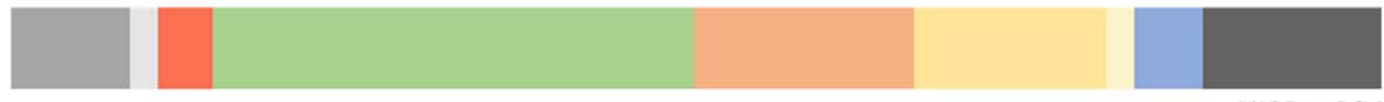

NISP $=294$

Phase 2
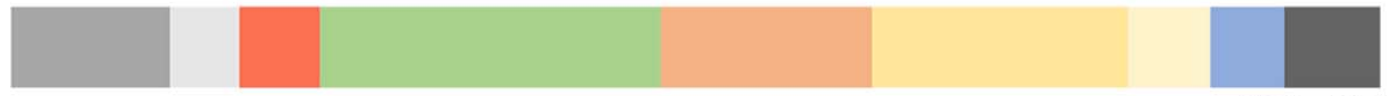

$\mathrm{NISP}=989$

Phase 1

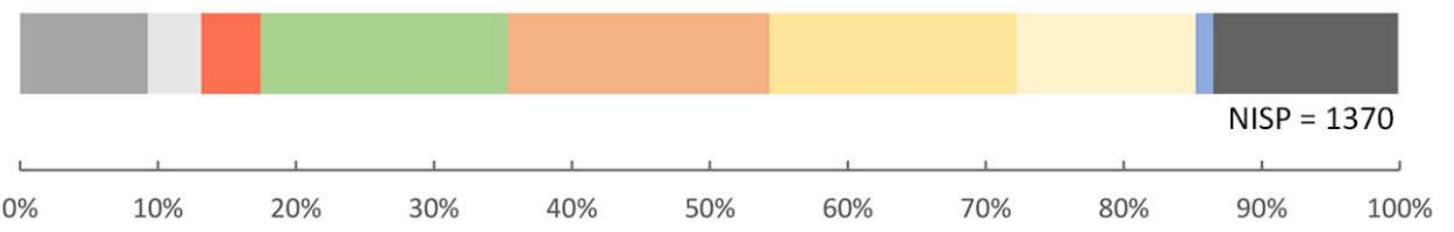

Figure 5. A. Spatial distribution of the most common fish families identified at MR11 Area A; B. Frequencies of the most common fish families identified throughout the phasing. 


\section{Conclusion}

The present study suggests that the oldest fishing activities documented in the Arabian Gulf were exclusively carried out in shallow coastal environments such as seagrass beds and mangroves with non-selective techniques (beach seines and tidal barrier traps). This opportunistic exploitation of the surrounding waters is well documented all along the Neolithic at sites situated in the Arabian Gulf where small seabreams and emperors constitute the major fish landings. The present study also outlines the importance of small grunts, which could be essentially identified by their otoliths. Fine sieving regularly points to the presence of sardines, anchovies and silversides. In the future, fine sieving ( 1 or $2 \mathrm{~mm}$ mesh) should be systematically undertaken in order to better evaluate the role of these small fish in ancient fisheries.

Since 2017, the excavations at MR11 have been extended to further Neolithic stone build houses located in the vicinity of Area $A$. These have also provided numerous fish remains which are currently under study. Comparative analyses will give us a better understanding of the organisation of what appears to be an ancient fishermens village. It seems that as far back as the Neolithic period, fish constituted a major part of the diet and a significant source of animal protein and lipid for the whole of Eastern Arabia.

\section{Acknowledgments}

We would like to thank H. E. Mohammed Khalifa Al Mubarak (Chairman of the Department of Culture and Tourism), Rita Aoun-Abdo (Executive Director, Culture Sector), Jaber Al Merri (Director of the Historic Environment Department) and Peter Magee (Head of Archaeology, Historic Environment Department) at DCT Abu Dhabi, for their support for our work on Marawah Island. Our thanks also to Mohammed Muftah Al Mansouri and Abdulla Ghanam bin Kadas al- Rumaithi who provided logistical support on the island. This study was also made possible for K.L. with the material and financial support of UMR 7209, UMR 6566, and ANR NeoArabia. Special thanks go to Dr Philippe Béarez (CNRS, UMR 7209 AASPE - Muséum National d'Histoire Naturelle, Paris) and Dr Sophie Méry (CNRS, UMR 5666 CREAAH Université de Rennes 1) for their advice and the supervision of the PhD thesis of one of us (K.L.).

Table 1. Table of identified fish from MR11 Area A, quantifications in NISP, MNI and WISP.

\begin{tabular}{llllll} 
Family & Genus & Species & NISP & MNI & WISP (g) \\
Hemiscylliidae & Chiloscyllium & Chiloscyllium sp. & 6 & 6 & 0.711 \\
Carcharhinidae & Carcharhinus & Carcharhinus amboinensis & 1 & 1 & 0.05 \\
& & Carcharhinus sp. & 10 & 4 & 2.064 \\
& ind. & ind. & 266 & 30 & 31.374 \\
Pristidae & ind. & ind. & 106 & 27 & 12.309 \\
Dasyatidae & ind. & ind. & 3 & 2 & 0.756 \\
\multicolumn{2}{rl}{ ind. Myliobatiformes } & & 66 & 20 & 2.854 \\
\multicolumn{2}{rl}{ ind. Chondrichthyes } & & 11 & 1 & 2.301
\end{tabular}


Total determinated Chondrichthyes

Total Chondrichthyes

\begin{tabular}{|c|c|c|c|c|c|}
\hline \multirow[t]{2}{*}{ Engraulidae } & Stolephorus & Stolephorus sp. & 1 & 1 & 0.007 \\
\hline & ind. & ind. & 19 & 2 & 0.013 \\
\hline Clupeidae & ind. & ind. & 6 & 2 & 0.011 \\
\hline \multirow[t]{3}{*}{ Ariidae } & Netuma & Netuma bilineata & 1 & 1 & 0.87 \\
\hline & & Netuma sp. & 1 & 1 & 0.32 \\
\hline & ind. & ind. & 6 & 6 & 1.642 \\
\hline Mugilidae & ind. & ind. & 3 & 3 & 0.107 \\
\hline Atherinidae & Atherinomorus & Atherinomorus lacunosus & 23 & 15 & 0.299 \\
\hline \multirow[t]{2}{*}{ Belonidae } & Tylosurus & Tylosurus sp. & 5 & 5 & 0.248 \\
\hline & ind. & ind. & 13 & 9 & 0.064 \\
\hline \multirow[t]{2}{*}{ Platycephalidae } & Platycephalus & Platycephalus indicus & 11 & 4 & 1.139 \\
\hline & ind. & ind. & 2 & 1 & 0.21 \\
\hline \multirow[t]{5}{*}{ Serranidae } & Cephalopholis & Cephalopholis hemistiktos & 1 & 1 & 0.055 \\
\hline & & Cephalopholis sp. & 2 & 2 & 0.025 \\
\hline & Epinephelus & Epinephelus coioides & 7 & 6 & 1.144 \\
\hline & & Epinephelus sp. & 103 & 66 & 49.112 \\
\hline & ind. & ind. & 18 & 13 & 2.474 \\
\hline Sillaginidae & Sillago & Sillago sihama & 13 & 10 & 0.546 \\
\hline \multirow[t]{9}{*}{ Carangidae } & Alepes & Alepes vari & 1 & 1 & 0.075 \\
\hline & & Alepes sp. & 1 & & 0.159 \\
\hline & Carangoides & Carangoides sp. & 12 & 5 & 2.159 \\
\hline & Caranx & Caranx sp. & 1 & 1 & 0.251 \\
\hline & Gnathanodon & Gnathanodon speciosus & 14 & 11 & 4.952 \\
\hline & Scomberoides & Scomberoides commersonnianus & 3 & 3 & 0.382 \\
\hline & & Scomberoides sp. & 1 & 1 & 0.111 \\
\hline & Selar & Selar sp. & 2 & 1 & 0.001 \\
\hline & ind. & ind. & 26 & 9 & 9.25 \\
\hline \multirow[t]{2}{*}{ Lutjanidae } & Lutjanus & Lutjanus malabaricus & 1 & 1 & 0.01 \\
\hline & & Lutjanus sp. & 34 & 18 & 1.34 \\
\hline \multirow[t]{2}{*}{ Gerreidae } & Gerres & Gerres longirostris & 2 & 2 & 0.105 \\
\hline & & Gerres sp. & 2 & 1 & 0.08 \\
\hline \multirow[t]{5}{*}{ Haemulidae } & Diagramma & Diagramma pictum & 4 & 3 & 0.4 \\
\hline & Plectorhinchus & Plectorhinchus sp. & 1 & 1 & 0.06 \\
\hline & Pomadasys & Pomadasys stridens & 625 & 407 & 33.795 \\
\hline & & Pomadasys sp. & 9 & 6 & 0.211 \\
\hline & ind. & ind. & 1 & & 0.033 \\
\hline Nemipteridae & Scolopsis & Scolopsis sp. & 1 & 1 & 0.013 \\
\hline \multirow[t]{5}{*}{ Lethrinidae } & Lethrinus & Lethrinus borbonicus & 4 & 3 & 0.189 \\
\hline & & Lethrinus lentjan & 2 & 1 & 0.29 \\
\hline & & Lethrinus microdon & 1 & 1 & 0.07 \\
\hline & & Lethrinus nebulosus & 105 & 88 & 7.906 \\
\hline & & Lethrinus sp. & 348 & 81 & 30.648 \\
\hline \multirow[t]{2}{*}{ Sparidae } & Acanthopagrus & Acanthopagrus arabicus & 37 & 24 & 11.4 \\
\hline & & Acanthopagrus berda & 1 & 1 & 0.02 \\
\hline
\end{tabular}

$\begin{array}{lll}458 & 90 \quad 50.118\end{array}$

$\begin{array}{lll}469 & 91 & 52.419\end{array}$

$469.91-52,419$

$1 \quad 1 \quad 0.007$

$\begin{array}{lll}9 & 2 & 0.013\end{array}$

$2 \quad 0.011$

87

107

248

064

055

9.112

474

075

159

952

382

111

105

4

033

013

89

29

07

.648 


\begin{tabular}{|c|c|c|c|c|c|}
\hline & & Acanthopagrus bifasciatus & 10 & 5 & 9.578 \\
\hline & & Acanthopagrus sheim & 1 & 1 & 0.142 \\
\hline & & Acanthopagrus sp. & 75 & 56 & 22.454 \\
\hline & Argyrops & Argyrops spinifer & 1 & 1 & 0.035 \\
\hline & Rhabdosargus & Rhabdosargus haffara & 137 & 92 & 22.46 \\
\hline & ind. & ind. & 227 & 41 & 20.431 \\
\hline \multicolumn{2}{|c|}{ ind. Sparoidea } & & 251 & 6 & 12.25 \\
\hline Sciaenidae & ind. & ind. & 4 & 1 & 0.021 \\
\hline Mullidae & ind. & ind. & 1 & 1 & 0.005 \\
\hline Terapontidae & Terapon & Terapon sp. & 3 & 2 & 0.104 \\
\hline Scaridae & Scarus & Scarus sp. & 4 & 3 & 0.32 \\
\hline Siganidae & Siganus & Siganus sp. & 17 & 10 & 0.313 \\
\hline \multirow[t]{2}{*}{ Sphyraenidae } & Sphyraena & Sphyraena putnamae & 1 & 1 & 0.033 \\
\hline & & Sphyraena sp. & 103 & 40 & 6.158 \\
\hline Scombridae & Euthynnus & Euthynnus affinis & 16 & 5 & 18.008 \\
\hline \multicolumn{2}{|c|}{ ind. Thunnini } & & 3 & 3 & 7.062 \\
\hline \multicolumn{2}{|c|}{ ind. Perciformes } & & 86 & & 5.175 \\
\hline \multicolumn{2}{|c|}{ ind. Teleostei } & & 4653 & 1 & 411.367 \\
\hline \multicolumn{3}{|c|}{ Total determinated Teleostei } & 2328 & 1087 & 281.57 \\
\hline & \multicolumn{2}{|c|}{ Total Teleostei } & 7067 & 1088 & 698.112 \\
\hline & \multicolumn{2}{|l|}{ Grand Total } & 7536 & 1179 & 750.531 \\
\hline
\end{tabular}

\section{References}

Abou-Seedo, F. (1992). Abundance of fish caught by stake traps (hadra) in the intertidal zone in Doha, Kuwait bay. Journal of the University of Kuwait (Science), 19, 91-99.

Al-Baz, A., al-Husaini, M., Bishop, J. (2013). Intertidal fixed stake net trap (hadrah) fishery in Kuwait: Distribution, catch rate and species composition. International Journal of Biological, Biomolecular, Agricultural, Food and Biotechnological Engineering, 7, 1114-1119.

Al-Lamy, J., Taher, M., al-Ali, A. (2012). Fish survey of inland lagoons and water surrounding Sammaliah Island - Abu Dhabi,
UAE. Mesopotamian Journal of Marine Science, 27, 104-111.

Beech, M. (2003). The development of fishing in the United Arab Emirates: A zooarchaeological perspective. In D. Potts, H. Naboodah, P. Hellyer (eds), Archaeology of the United Arab Emirates: Proceedings of the First International Conference on the Archaeology of the UAE. London: Trident Press, 289-308.

Beech, M. (2004). In the land of the Ichthyophagi: Modelling fish exploitation in the Arabian Gulf and Gulf of Oman from the 5 th millennium BC to the late Islamic period. (Abu Dhabi Islands Archaeological Survey 
Monograph, 1. BAR IS 1217). Oxford: Archaeopress.

Beech, M. (2010). The animal and fish bones. In R. Carter, H. Crawford (eds), Maritime interactions in the Arabian Neolithic. Evidences from H3, As-Sabiyah, an Ubaid-related site in Kuwait. (American School of Prehistoric Research Monograph Series, 8). Boston: Brill, 129-156

Beech, B., Cuttler, R., Moscrop, D., Kallweit, H., Martin, J. (2005). New evidence for the Neolithic settlement of Marawah Island, Abu Dhabi, United Arab Emirates. Proceedings of the Seminar for Arabian Studies, 35, 37-56.

Beech, M., Strutt, K., Blue, L., al-Kaabi, A., Omar, W., al Haj el-Faki, A., Lingareddy, A., Martin, J. (2016). 'Ubaid-related sites of the southern Gulf revisited: the Abu Dhabi Costal Heritage Initiative. Proceedings of the Seminar for Arabian Studies, 46, 9-24.

Cavulli, F. \& Scaruffi, S. (2013). Thoughts on nomadism in Middle Holocene Oman. Arabian Archaeology and Epigraphy, 24, 15-27.

Chaplin, R. (1971). The study of animal bones from archaeological sites. New York: Seminar Press.

Charpentier, V. (2004). Trihedral points: an new facet to the "Arabian Bifacial Tradition"? Proceedings of the Seminar for Arabian Studies, 34, 53-66.

Charpentier, V., Méry, S., Fortini, E., Pellé, E. (2009). "Un chef est un requin qui voyage par terre": fonctions et statues des armatures de projectile en dent de Carcharhinus leucas et aiguillon caudal de raie dans I'Arabie des Vle-Ille millénaires av. notre ère. Arabian Archaeology and Epigraphy, 20, 9-17.

Charpentier, V., Berger, J.-F., Crassard, R., Borgi, F., Béarez, P. (2016). Les premiers chasseurs-collecteurs maritimes d'Arabie (IXe-IVe millénaires avant notre ère). In $\mathrm{C}$. Dupont, G. Marchand (dir). Actes de la séance de la Société préhistorique française de Rennes, 10-11 avril 2014. Paris: Société Préhistorique Française, 345-365.

Cleuziou, S. \& Tosi, M. (2007). In the shadow of the ancestors. The prehistoric foundations of the early Arabian civilization in Oman. Muscat: Ministry of Heritage and Culture, Sultanate of Oman.

Coutureau, M. \& Béarez, P. (2012). Lutjanus Bloch, 1790. ArchéoZoo. Retrieved from www.archeozoo.org/archeozootheque/gal leries/file uploader/pdf/lutjanus spp.pdf

Desse, J. (1988). Khor P., Khor F.B. \& Shagra. Les faunes, le rôle de la pêche. In M.-L. Inizan (ed), Préhistoire à Qatar, Mission archéologique française à Qatar, 2. Paris: Éditions Recherche sur les Civilisations, 157-166.

Evans, G., Kirkham, A., Carter, R. (2002). Quaternary Development of the United Arab Emirates Coast: New Evidence from Marawah Island, Abu Dhabi. GeoArabia, 7, 441-458.

Heard-Bey, F. (1986). From Trucial States to United Arab Emirates. London \& New York: Longman Group.

Iwatsuki, Y. (2013). Review of the Acanthopagrus latus complex (Perciformes: Sparidae) with descriptions of three new species from the Indo-West Pacific Ocean. Journal of Fish Biology, 83, 64-95.

Jabado, R., al-Ghais, S., Hamza, W., Shivji, M., Henderson, A. (2015). Shark diversity in the Arabian/Persian Gulf higher than 
previously thought: insights based on species composition of shark landings in the United Arab Emirates. Marine Biodiversity, 45, 719-731.

Jabado, R., al-Baharna, R., al-Ali, S., alSuwaidi, K., al-Blooshi, A., al-Dhaheri, S. (2017). Is this the last stand of the critically endangered green sawfish Pristis zijsron in the Arabian Gulf? Endangered Species Research, 32, 265-275.

Jabado, R., Kyne, P., Pollom, R., Ebert, D., Simpfendorfer, C., Ralph, G., al-Dhaheri, S., Akhilesh, K., Ali, K., Ali, H., al-Mamari, T., Bineesh, K., el-Hassan, I., Fernando, D., Grandcourt, E., Khan, M., Moore, A., Owfi, F., Robinson, D., Romanov, E., Soares, A.-L., Spaet, J., Tesfamichael, D., Valinassab, T., Dulvy, N. (2018). Troubled waters: Threats and extinction risk of the sharks, rays and chimaeras of the Arabian Sea and adjacent waters. Fish and Fisheries, 19, 1043-1062.

Kanashiro, K. (1998). Settlement and Migration of Early Spangled Emperor, Lethrinus nebulosus (Pisces: Lethrinidae), in the Coastal Waters off Okinawa island, Japan. Nippon Suisan Gakkaishi, 64, 618625.

King, G. (1998). Abu Dhabi Islands archaeological survey. London: Trident Press.

Lidour, K. \& Beech, M. (2019). 'The numerous islands of Ichthyophagi': Neolithic fisheries of Delma Island, Abu Dhabi Emirate (UAE). Proceedings of the Seminar for Arabian Studies, 49, 207-222

Lidour, K., Vorenger, J., Béarez, P. (2018). Size and weight estimations of the spangled emperor (Teleostei: Lethrinidae: Lethrinus nebulosus) from bones measurements elucidate fishing grounds exploited and ancient seasonality at Akab (United Arab Emirates). International Journal of
Osteoarchaeology, 1-14. doi: https://doi.org/10.1002/oa.2683

Lidour, K., Béarez, P., Charpentier, V., Méry, S. (2019). The prehistoric fisheries of Akab Island (United Arab Emirates). New insights into coastal subsistence during Neolithic in eastern Arabia. Journal of Island and Coastal Archaeology. doi: $\underline{10.1080 / 15564894.2018 .1531330}$

Mashkour, M., Debue, K., Yeomans, L., Brehard, S., Gasparini, D., Méry S. (2016). Middle to Late Neolithic animal exploitation at UAQ2 (5500-4000 cal. BC): An 'Ubaid-related coastal site at Umm alQuwain Emirate, United Arab Emirates. Proceedings of the Seminar for Arabian Studies, 46, 195-210.

Méry, S., Blackman, M., Beech, M., Lidour, K. (2016). 5500 av. notre ère : le vase de Marawah MR11 et l'Obeid du Golfe. In B. Perello, A. Tenu (dir), Parcours d'Orient. Recueil de textes offert à Christine Kepinski. Oxford: Archaeopress Archaeology, 155174.

Sanlaville, P. \& Dalongeville, R. (2005). L'évolution des espaces littoraux du Golfe persique et du Golfe d'Oman depuis la phase finale de la transgression postglaciaire. Paléorient, 31, 9-26.

Santini, G. (2002). Burial complex 43 at the Prehistoric graveyard of Ra's al-Hamra in northern Oman. In S. Cleuziou, M. Tosi, J. Zarins (eds), Essays on the Late Prehistory of the Arabian Peninsula. (Serie Orientale Roma, 93). Roma: Instituto Italiano per I'Africa e l'Oriente, 147-167.

Serjeant, R. (1992). The Coastal Population of Socotra. In B. Doe (ed), Socotra: The Island of Tranquility. London: Immel, 133180. 
Sheaves, M. (1995). Large lutjanid and serranid fishes in tropical estuaries: are they adults or juveniles? Marine Ecology Progress Series, 129, 31-40.

Stuiver, M. \& Reimer P.J. 1993. Extended $14 \mathrm{C}$ data base and revised CALIB $3.014 \mathrm{C}$ age calibration program. Radiocarbon, 35, 215-230.

Thollot, P. (1996). Les poissons de mangrove du lagon sud-ouest de NouvelleCalédonie. Paris: ORSTOM.

Uerpmann, M. \& Uerpmann, H-P. (2018). Faunal remains and subsistence strategies. In Drechsler, P. (Ed.), Dosariyah. Reinvestigating a Neolithic coastal community in eastern Arabia. (British Foundation for the Study of Arabia Monograph, 19). Oxford: Archaeopress, 384-422.

Von den Driesch, A. \& Manhart, H. (2000). Fish bones from al-Markh, Bahrain. In M. Mashkour, A. Choyke, H. Buitenhuis, F. Poplin (eds), Archaeozoology of the Near East IV. Proceedings of the fourth international symposium on the archaeozoology of southwestern Asia and adjacent areas. Groningen: ARC, 50-67.

Weistein, M. \& Heck, K. (1979). Ichthyofauna of Seagrass Meadows Along the Caribbean Coast of Panama and in the Gulf of Mexico: Composition, Structure and Community Ecology. Marine Biology, 50, 97-107.

Wheeler, A. \& Jones, A. (1989). Fishes. Cambridge: Cambridge University Press.

White, G. (1937). Interrelationships of the Elasmobranchs with a Key to the Order Galea. Bulletin of the American Museum of Natural History, 74, 25-138. 